\title{
How Higher Education Institutions Are Driving to Digital Transformation: A Case Study
}

\author{
Andreia Filipa Teixeira ${ }^{1}$, Maria José Angélico Gonçalves ${ }^{2, *(\mathbb{D}}$ and Maria de Lourdes Machado Taylor ${ }^{3}$ \\ 1 Polytechnic of Porto, 4200-465 Porto, Portugal; filipa.afdrt@gmail.com \\ 2 CEOS.PP, Polytechnic of Porto, 4200-465 Porto, Portugal \\ 3 Center for Research on Higher Education Policies (CIPES), 4450-227 Matosinhos, Portugal; \\ mmachadotaylor@gmail.com \\ * Correspondence: mjose@iscap.ipp.pt; Tel.: +351-229050000
}

Citation: Teixeira, A.F.; Gonçalves, M.J.A.; Taylor, M.d.L.M. How Higher Education Institutions Are Driving to Digital Transformation: A Case Study. Educ. Sci. 2021, 11, 636. https:// doi.org/10.3390/educsci11100636

Academic Editors:

Tatiana Evtushenko, Daria Bylieva and Klochkova Elena

Received: 6 September 2021

Accepted: 2 October 2021

Published: 13 October 2021

Publisher's Note: MDPI stays neutral with regard to jurisdictional claims in published maps and institutional affiliations.

Copyright: (c) 2021 by the authors. Licensee MDPI, Basel, Switzerland. This article is an open access article distributed under the terms and conditions of the Creative Commons Attribution (CC BY) license (https:/ / creativecommons.org/licenses/by/ $4.0 /)$.

\begin{abstract}
In recent years, the rapid development of technological innovation has transformed the business world. Digital transformation improves the economic positioning of companies, contributing to society and the environment, but beyond technological evolution, it also brings social and cultural changes. With the new trends, companies saw the need to train people with digital skills and higher education institutions (HEIs) were forced to change their teaching methods to keep up with the new demands of the labour market. In this context, it is intended to identify the influence that HEIs play in the digital development of regions, in this case, the influence of Public Polytechnic Institutes of Porto in the development of the Metropolitan Area of Porto. The methodology adopted to answer the objectives of this study and research questions formulated, was an exploratory study, using semi-structured interviews and questionnaires. The results obtained allowed us to verify the positive influence of HEIs in the digital development of the Metropolitan Area of Porto. As well as identify the motivations that lead companies to participate in digital transformation initiatives, identify the skills needed to meet the demands of the labour market and identify the efforts made by HEIs to keep up with the digital evolution of society.
\end{abstract}

Keywords: digital transformation; Industry 4.0; higher education; innovation

\section{Introduction}

The globalization and economic internationalization that has taken place in recent years is essentially due to the growing political, economic and financial interdependence of relations between different countries [1]. To ensure business development and add value, digital technologies have been integrated within organizations, with the aim of improving their products and services [2,3]. The innovation of production and business processes, the implementation of intelligent machines and appliances, offers countless benefits in terms of production productivity, resource efficiency and reduction of waste [4].

With the new trends, as well as the new skills required by the labour market [5], companies and higher education institutions (HEIs) saw the need to train people with digital skills and basic programming knowledge [6]. Competitiveness in higher education has been growing between Institutions and Countries and European universities have changed their teaching methods [7], to prepare increasingly more qualified professionals in different areas of knowledge [8].

The main objective of this study was to identify the influence that HEIs play in the digital development of regions, especially the Public Polytechnic Institutes in the Metropolitan Area of Porto. The methodology adopted to respond to the objectives of this study and formulated research questions was an exploratory study, using semi-structured interviews and questionnaires. The analysis of the interviews and the results obtained from the questionnaires allowed us to verify the positive influence of HEIs in the digital development of the regions of the Metropolitan Area of Porto. As well as identifying the 
motivations that lead companies to adopt the digital transformation, the skills needed to respond to the new demands of the labour market and the strategy adopted by HEIs to follow the digital evolution of society.

After this brief introduction, the following section presents a literature review, with a quick reference to higher education, the concept of digital transformation and the role of higher education in digital transformation. The third section presents the context of the research. Then, in the fourth, the questions, objectives, research method-ology, and results from data collection and analysis of interviews and questionnaires are presented. Finally, the fifth section presents the conclusions of the study, the limi-tations, as well as the expectation for future work.

\section{Literature Review}

In recent years, society has been living in constant novelty and technological innovation, at a fast pace, due to the digital transformation, which in the last decades has been changing the world [9]. In fact, digital transformation has become a multidisciplinary research topic, transversal across the scientific community, such as human resources, marketing, financial processes and innovation [10]. Digital transformation is much more than just services and processes innovation [11]. It involves fundamental changes in organisational procedures and capacity [10] and in the cognitive bases of businesses, which are now based on intangible knowledge bases [12]. In this sense, in the next subsection we address the current economic context of the country and the importance of innovation and digital transformation for society.

\subsection{The Portuguese Economy and Digital Transformation}

In the current context of globalisation and European integration, economic growth is essential to improve the quality of life and solve economic and social problems [13]. Globalisation implies changes in the organisation of economic activity and the "ability to sustain industries that are globally competitive" [14]. In the 1990s, Michael Porter introduced the idea of cluster in a geographical economic dimension to promote growth and regional competitiveness [15]. Clusters are geographic concentrations of certain economic activities, firms and institutions [16], and are determinants for the economic evolution of regions [17]. They increase industrial diversification and innovation, create value and job opportunities, and allow small and medium-sized enterprises (SMEs) to develop their activities globally [14]. In 1992, the Portuguese Government asked Porter for a study to promote the development and competitiveness of Portuguese companies and industries [18].

Portugal has quality and governing efficiency, has political stability and absence of violence or terrorism, the economic indicator that registers the highest economic growth, as well as, quality, is education [19]. In this context, the country's management capacity is expected to improve with the quality of management schools and public reforms are tailored to macroeconomic objectives [18]. There is a positive relationship between higher education growth and regional economic growth, a 10\% increase in the number of academic units is, as a rule, associated with a $0.4 \%$ increase in the region's GDP per capita [20]. This effect has a greater impact in the less developed regions of the country. The contribution of HEIs is not only confined to the region where they are located, but also to neighbouring regions, with their impact being stronger on geographically closer regions [20,21]. Clusters evolve, undergo transformations, grow and may even disappear [15], but Porter's strategy is still valid and the country can benefit from the development of its competitiveness in science, technology and education [18]. Historically, HEIs have been a policy instrument for regional economic, social and sustainable development $[17,18,22]$ and companies that benefit from clusters, execute their activities better and are more productive.

The term digital transformation is attributed to various forms of technological innovation, both in industry and society. It refers to the process of globalisation and adaptation of communities, organisations and nations, to digitalisation [23]. Companies adopt digital transformation to improve their business strategies, differentiation and competitiveness [24]. 
Digital transformation, namely, Industry 4.0, is the implementation and integration of a variety of digital information and operation technology, as well as, industrial sensors and controllers, self-driving vehicles, robots, augmented and virtual reality, data analytics, cloud computing, internet of services (IoS), design and production aided by high-performance, computer-based computing and artificial intelligence (AI) [4].

Research in the field of Industry 4.0 has been growing due to innovation in production systems [25]. Since the 1st industrial revolution in the 18th century, the world has been dealing with overproduction of goods and high consumption of natural resources, which have caused major negative social and environmental impacts [4]. The contribution of Industry 4.0 to the sustainability of the economy, the environment and social development is attracting an increasing amount of attention. Sustainability protects the environment and preserves the economy and social resources [4]. Business sustainability was proposed by [26], and some studies have proposed the contribution of Industry 4.0 to achieve sustainability goals [27]. However, there is still a lack of understanding of the models and tools that can help companies integrate sustainability into their business activities [23].

According to the UNESCO National Commission, investing in technology, researching, and creating knowledge through science allows addressing economic, social and environmental challenges and achieving sustainable development. UNESCO further reinforces that "international scientific cooperation contributes not only to scientific knowledge but also to peacebuilding" [28].

From Mergel's [11] point of view, it is not only the private sector which is investing in digital transformation. Public administrations also must manage citizens' expectations and create value in digital services. For this reason, governments have been changing their ways of doing things to improve service delivery, efficiency, and design to achieve transparency and citizen satisfaction [11]. In the public sector, digital transformation means new ways of working with stakeholders, adopting new delivery service practices and creating ways to engage with markets [11].

To help countries identify the strengths and weaknesses of national innovation systems, the EU has created the Regional Innovation Scoreboard (RIS), which assesses innovation performance in European regions based on indicators, which allow the economical, commercial and social differences between regions to be analysed and compared [29].

The next subsection presents the importance of the role, which higher education plays in the digital transformation of society.

\subsection{The Role of Higher Education in Digital Transformation}

Despite the contribution of innovation in society in a world of constant discovery, it is necessary that education, and higher education in particular, keeps up with technological development, in order to qualify and instruct people with the necessary knowledge, to understand science and make their professional, personal and political choices [28]. Digital technologies have assumed an increasingly important role in higher education methods and digital transformation initiatives are the focus of a new generation of EU policies for 2020 [30]. The main challenges of innovation involve strengthening the european higher education area and ensuring its quality through internal and external resources, such as quality assurance mechanisms [31].

As such, it is necessary for HEIs, businesses and governments to update strategic plans and define the implementation of specific actions for Industry 4.0, such as increasing stakeholder engagement, establishing innovative resources for higher education students and creating postgraduate courses in creative Industry 4.0 strategies to develop skills and cultivate experience [32]. In recent years, digital transformation has revolutionised the role of marketing in companies, the labour market has largely shifted to online platforms, and job opportunities in digital, analytics and technology have expanded [33]. This effect is also reflected in employability and requires specific knowledge in digital tools, in a world where education is increasingly affordable, and academic education becomes more and more entrepreneurial and pays special attention to the expectations of businesses, govern- 
ments, students and other stakeholders [33]. The increasing pressure for sustainability and financial stability, and the global competitiveness of the market, have led higher education to show evidence of formative quality and to use learning analytics to find solutions to the issues of student progression, student experience and satisfaction, teaching quality and innovation, and institutional performance and ranking [34].

The use of technology in education is a competitive and innovative strategy. The evolution of technologies facilitate access to higher education and the success of online resources used in face-to-face and distance education [35]. The great feature of higher education is to train competent and committed citizens to the scientific and technological development of the area in which they work [8]. Digital technologies based on web tools or social networks, are resources that promote communication between students and teachers, mainly because they are tools that can be used in each one's social and daily life [30].

HEIs are institutions that have adapted to various political, social and technical changes, and currently have to adapt to a dynamic and technological environment, in a digitally evolving world [36]. The next sections present the research context and the details of the methodology followed in this study.

\section{Research Context: Higher Education in Portugal: Porto Polytechnic Case}

In Portugal, HEIs are organised in a binary system, integrating university and polytechnic education, which may be public or private and should ensure access to all citizens who meet the requirements and conditions for admission to higher education [37]. The polytechnic institutes emerged to expand higher education in the country, were located where there were no universities and the training offer was designed to respond to the needs of the labour market in the respective regions [38].

The Polytechnic Institute of Porto, which integrates eight public institutes spread over three campuses, 24 research centres and offering 56 degrees and 62 masters degrees, a variety of specialized training to over 18 thousand students was founded in 1985 [39]. Students also have available two doctorates in the areas of Biotechnology and Education, due to partnerships with universities of Salamanca, Santiago de Compostela and Vigo in Spain, giving preference to internationalisation strategies [39]. It provides training and research in business; engineering; music, arts, and entertainment; health; education; hospitality and tourism; management and media, art and design and multimedia.

At an international level, the Polytechnic of Porto is recognized for its interaction with the world of work, for its strong orientation towards teaching in real contexts and for the development of transversal skills, entrepreneurship, and culture. It participates in several European and intercontinental leadership projects, from the USA to Latin America, Africa, or Asia, in diverse and highly competitive areas of knowledge, such as biotechnology, energy and technology. Examples include the 3P's project, which was awarded to Portugal by the European Research Council, and which involves nanomaterials and biosensors to detect cancer. The European project P-SOCRATES, which integrates a parallel software structure. DREAM-GO, a project in Intelligent Electricity Networks. The EU Horizon 2020 programme, the GMOSensor project in Brazil and Argentina, in the area of biosensors for the environment and food, and the VISIR+ project, for the construction of a network of remote laboratories [39]. The next table presents a SWOT Analysis, with the main threats and opportunities, strengths, and weaknesses, of the external and internal environment of higher education institutions (Table 1). 
Table 1. SWOT Analysis.

\begin{tabular}{|c|c|}
\hline Strengths & Weaknesses \\
\hline $\begin{array}{l}\text { International recognition of the quality of HEIs [1]. } \\
\text { Quality of resources [31]. } \\
\text { Research [40]. } \\
\text { Prestige/Quality/Recognition of the qualification of graduates [1]. } \\
\text { Growing participation in projects and creation of national and } \\
\text { international partnerships [7]. } \\
\text { Cooperation with stakeholders and the business sector [5]. }\end{array}$ & $\begin{array}{l}\text { Strengthen the qualification of the teaching staff and } \\
\text { mobility between institutions [38]. } \\
\text { Reduced financial support [31]. } \\
\text { Duplication of the formative offer between institutions [1]. } \\
\text { Quality Communication [36]. } \\
\text { Small number of full-time researchers and weak } \\
\text { multidisciplinary research [41]. } \\
\text { Low level of e-learning [34]. }\end{array}$ \\
\hline Opportunities & Threats \\
\hline $\begin{array}{l}\text { Internationalization and globalization [31]. } \\
\text { Lifelong learning [6]. } \\
\text { Technological innovation [36]. } \\
\text { Diversity of formative offer [42]. } \\
\text { New teaching methods [5]. } \\
\text { Alumni Network [5]. } \\
\text { Valuing the transmission of knowledge to society [36]. }\end{array}$ & $\begin{array}{l}\text { Problems related to demographic change and the economic } \\
\text { context [17,18]. } \\
\text { Financial Instability of the European Union [43]. } \\
\text { International Rankings [34]. } \\
\text { Accountability and continuous reduction of public funding } \\
\text { [10,19]. } \\
\text { Lack of cooperation between HEIs [34]. } \\
\text { Standards of Accreditation Agencies [1]. } \\
\text { Professional expectations and labour market demands [42]. }\end{array}$ \\
\hline
\end{tabular}

The economic benefits of teaching quality and investment in education have been visible in recent decades, mainly in the wage return of graduates in the areas of engineering sciences, mathematics and technology [19].

\section{Research Issues, Objectives and Methodology}

The selection of the research methodology to be applied always depends on the phenomenon to be studied [44]. To answer the study objective and, consequently, the research questions formulated, a descriptive exploratory study with a qualitative and quantitative approach was conducted. According to the literature, combining the qualitative and quantitative approaches, on the one hand, we wanted to obtain precise data and, on the other, to understand the world more fully.

According to Fortin ([45], p. 51), the research question is defined as: "an explicit question concerning a domain that should be explored in order to obtain new information". Thus, considering the problematic and the purpose of the study, we defined the following research question:

What is the influence of Public Polytechnic Institutes on Regional Digital Development in the Porto Metropolitan Area?

To provide an operational answer to the previous question, a group of sub-questions should first be answered, considering the challenges for higher education mentioned in Section 2.2.

RQ1. What are the main motivations for companies to adopt digital transformation?

RQ2. What skills are needed for young people to enter the labour market?

RQ3. What is the strategy of HEIs to respond to the digital evolution of society?

RQ4. How do HEIs contribute to the digital development of the regions where they operate?

This study aims to understand the importance of digital transformation and Industry 4.0 in society. As well as identify the strategies developed by higher education institutions (HEIs) to follow and contribute to the economic and social development of the regions.

The work began by collecting data through semi-structured interviews. Interviews are often used as a qualitative research method [46] and may take a more or less structured form [47]. Semi-structured interviews are conducted using flexible scripts and structured interviews using more rigid scripts [48]. As such, considering the objectives of this work, the interviews conducted were semi-structured so that the results would be more productive, and the interviewees would participate actively. 
Then, a questionnaire was launched, directed to the alumni of the Public Polytechnic Institutes of the Metropolitan Area of Porto, namely the Polytechnic Institute of Porto, to know their experiences and future perspectives in the labour market, and how higher education can contribute and respond to the demands of the stakeholders. The following section presents the referred data collection techniques.

\subsection{Data Collection Process}

Techniques used for empirical data collection were interviews and questionnaires

The interviews were conducted between July and October 2020 and the invitations were made by email or telephone contact, as well as the scheduling of the interviews. Of the 12 people invited, 10 agreed to grant the interview and two of the invited people ended up not having availability. Of the 10 participants, four were HEI professionals, four employers (executive level) and two alumni (see Table 2). The interviews were semi-structured, and questions were pre-defined according to each participant's profile. The interview questions were developed to investigate the interviewee's familiarity with the terms digital transformation and Industry 4. 0, the training and experience with technological innovation, the main motivations of organisations for the adoption of digital transformation, the implementation processes adopted, the response of organisations to stakeholders' demands and digital evolution of society, the skills required for the integration of recent graduates in the labour market, the need for specialised training of employees, as well as, the development of partnerships between companies and HEIs, investigate the contribution of higher education in preparing students and the contribution of higher education to regional digital development, and possible future expectations of the interviewees on new methods of education and lifelong learning (see scales in [49] (p. 120)).

Table 2. Profile of interviewees.

\begin{tabular}{|c|c|c|c|c|c|}
\hline \multirow{2}{*}{ Profile } & \multicolumn{4}{|c|}{ Education } & \multirow{2}{*}{ Actual Work Position } \\
\hline & Area & Year & Institution & Degree & \\
\hline Executive & $\begin{array}{l}\text { Chemical } \\
\text { Engineering }\end{array}$ & 1988 & ISEP & Master & General Manager \\
\hline Alumni & $\begin{array}{l}\text { Chemical } \\
\text { Engineering }\end{array}$ & 1986 & ISEP & Bachelor & Consultant/Trainer \\
\hline Executive & $\begin{array}{l}\text { Chemical } \\
\text { Engineering }\end{array}$ & 1995 & ISEP & Master & Energy and Project Director \\
\hline Executive & $\begin{array}{l}\text { Chemical } \\
\text { Engineering }\end{array}$ & 1986 & FEUP & Master & CINCA Technical Director \\
\hline Executive & Civil Engineering & 1985 & ISEP & Bachelor & Director of the Nasamotor \\
\hline Alumni & $\begin{array}{l}\text { Electrical } \\
\text { Engineering }\end{array}$ & 1988 & FEUP & Bachelor & President of the Alumni ISEP \\
\hline HEI & $\begin{array}{c}\text { Electrical } \\
\text { Engineering }\end{array}$ & 1997 & FEUP & Bachelor & $\begin{array}{c}\text { Lecturer, Researcher, Senior IT } \\
\text { Technician }\end{array}$ \\
\hline HEI & $\begin{array}{l}\text { Computer } \\
\text { Engineering }\end{array}$ & 1993 & ISEP & PHD & $\begin{array}{l}\text { Lecture, Researcher and Member of the } \\
\text { Management Board }\end{array}$ \\
\hline HEI & $\begin{array}{l}\text { Computer } \\
\text { Engineering }\end{array}$ & 1999 & ISEP & PHD & Lecturer and Researcher \\
\hline HEY & $\begin{array}{c}\text { Languages and } \\
\text { Modern } \\
\text { Literatures }\end{array}$ & 1996 & FLUP & PHD & Vice-Chairman of HEI \\
\hline
\end{tabular}

Due to the constraints caused by COVID-19, on communication and movement of people, all interviews were carried out virtually or by mobile networks, namely Teams, Zoom, e-mail or by phone call. The interviews lasted an average of approximately $25 \mathrm{~min}$, with the longest taking $34 \mathrm{~min}$ and the shortest $16 \mathrm{~min}$. Of the 10 participants, two preferred to respond to the interview in writing. 
All interviews were conducted in the presence of only the researcher and the interviewee. All interviews were audio recorded, with the consent of the participants, to improve the quality of the analysis. The interviews were organised into three moments, the initial moment, the interview moment, and the final moment. At the initial moment, the objectives of the research study and the ethical and legal considerations, such as confidentiality and data disclosure, were mentioned. At the moment of interview, the previously structured questions were asked based on the interviewee's profile and based on the interview script validated by the research study of [34].

After all interviews were conducted, the process of data transcription, analysis and interpretation began. WebQda software, which allows structuring and coding all the collected material, was used for data organization. Initially, data analysis consisted of reading, coding, and interpreting the interviews and, finally, a joint analysis of the interviews conducted.

A questionnaire was then launched, aimed at the alumni of the Public Polytechnic Institutes of the Metropolitan Area of Porto, namely the IPP, described in Section 2 (see scales in ([49], p. 147)). This questionnaire aimed to find out about the experiences and future perspectives in the labour market and how higher education can contribute and respond to stakeholders' demands.

For the questionnaire we chose to use forms with scales validated in other research projects, with similar questions, namely the form of a study of the European Economic and Social Committee [50] and the form of the U-Value Project [51].

The questionnaire is organised into four sections: Profile, Perception, Participation and Contribution, and consists of 23 questions. The first section identifies the interviewee's profile, area of training, academic qualifications, and professional career. The Perception section, aims to identify the main motivations and challenges for the implementation of digital transformation, identify the main advantages and disadvantages of the adoption of digital transformation, identify the level of importance to acquire new digital skills and identify the contribution of higher education in preparing students for the labour market. The Participation section identifies the involvement of organisations in innovation and development projects and the origin of investments for the projects. The last section, aims to identify the contribution of higher education to regional digital development, identify the main resources of HEIs that contribute to regional development and identify the positive effects of HEIs in the regions where they operate. In some questions, the response method adopted was open-ended and free response for the cases in which it did not apply. Likert scales were also used to measure the levels of importance and agreement. For the launching of the questionnaire a random sample was selected by convenience that counted with the alumni of the Polytechnic of Porto, to assess the perception of former students, regarding the contribution of higher education in the acquisition of skills, essentially digital, required by the labour market. This type of sample is not considered representative of the population; however, according to [52], it is the most useful to capture general ideas, as well as to identify critical aspects to be analysed.

The questionnaire was developed in Google Forms and was disseminated by email to the network of former students of ISCAP and ISEP and shared by the network of personal and professional contacts through social networks such as LinkedIn and Facebook. The questionnaires were distributed between October and November 2020, and we obtained 37 responses (see Table 3). Data analysis was conducted in SPSS environment, version 22. In characterizing the sample and describing the variables, absolute (n) and relative (\%) frequencies were used. To assess the association between categorical variables, the chi-square test was used. Alternatively, Fisher's test was used in case of non-compliance with the assumption of a maximum of $20 \%$ of cells with expected frequency below 5 in the contingency table. The significance level considered for rejection of the null hypothesis was $5 \%$. 
Table 3. Respondents' profile.

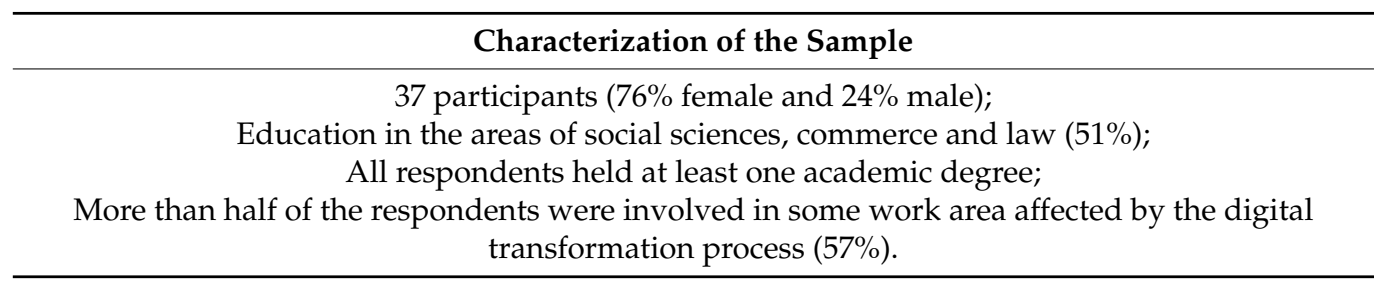

Having identified the methodology, the research questions, and the objective of this study, we consider that the conditions are met to present the results obtained in the interviews and questionnaires in the following section.

\subsection{Results}

In this section the main ideas and conclusions produced in the analysis of the interviews and questionnaires were summarised to relate the results obtained. Given the specificity of the sample, it was decided to present the results indicating their origin (interviews or questionnaire).

\subsubsection{Motivations and Challenges}

This field intends to identify the motivations and challenges of organisations and educational institutions for the adoption and implementation of digital transformation.

During the interviews and questionnaires, participants identified the main motivations and challenges for the adoption and implementation of digital transformation in organisations. In the interviews, it was observed that the main drivers for companies to adopt digital transformation are customer contact, process optimisation, information collection, control, cost reduction and competitiveness. Phrases such as "Contact with the client, productivity and profitability", as well as "(...) optimisation of processes, collection of information, synthesis of information, speed, access to and standardisation of information, from the administrator to the operator", "control, knowledge of the process, cost reduction and mechanised work" and "competitiveness, leadership, proximity to the client (...)" were mentioned as the main motivations. In the questionnaires, the results indicate that the main motivations for the implementation of digital transformation are related to customer expectations, business growth $(56 \%)$ and business model innovation $(43.2 \%)$. It was also found that respondents who had worked in the sector for up to 5 years more often agreed that the personalisation of services was a motivation for the implementation of digital transformation, unlike respondents who had worked in the sector for more than 5 years. In the literature review, it was also found that companies have adopted digital transformation, to improve their business strategies, differentiation and competitiveness [24].

In terms of challenges, the interviews highlighted the slow evolution of the digital transformation process, which tends to be reflected to a greater extent in the financial and administrative areas than in the industrial area, for example, because it requires less investment and faster implementation. During the interviews, it was mentioned that "This type of transformation in the industry is gradual and depends on the industries. It is the case of the electronics industry or more developed industries, which have a faster equipment rotation, or the automotive industry, which are advanced industries with a faster digital transformation process", in the case of HEIs, "RED centres are undoubtedly the ones that most contribute to innovation, through the promotion of their mission, which is to contribute and participate in the development of sustainable solutions to current and emerging challenges. In addition to investment, employee training was also mentioned as a challenge to the implementation of digital transformation, because there is not always the time and availability to train people, stated as follows, it takes a lot of effort in terms of self-learning, and we do not always have the time and training required". In the questionnaires, the results revealed that the main challenges are cultural and behavioural resistance $(67 \%)$, lack of change-oriented mind set and lack of understanding of digital trends (54.1\%). The results further revealed, that 
for respondents with more than 5 years of working time, low functional collaboration is a challenge as opposed to respondents with industry time of 5 years or less. Already in the literature review, one of the challenges pointed out was efficiency, because for decisionmakers, one of the main challenges, is to achieve a more efficient management, to improve competitiveness [41].

\subsubsection{Skills and Participation}

Regarding skills, both in the interviews and in the questionnaires, participants identified the importance of acquiring new skills with digital trends and referred to the participation or collaboration in research, innovation, and development projects.

In the analysis of the interviews, it was found that it is common sense that the acquisition of new skills is necessary so that people can be integrated in the labour market with differentiated training and increasingly demanding functions in terms of technological knowledge. One of the characteristics most mentioned by the interviewees, in addition to technical and scientific knowledge, was flexibility and the ability to adapt to the different variables of the labour market, companies and society, "When companies started to have automation processes, it became more important, at the level of plant operators and managers, for greater adaptability and flexibility", "that is, the ability a person has to adapt to different functions or requirements". In the questionnaires, the results indicate (with more than $50 \%$ ) that it is very important to acquire new skills to respond to the new demands and evolution of the labour market.

In the literature review, [5] also mentioned, that professionals and higher education students, should follow the evolution and changes required by the labour market, and develop their skills. For Kaplan and Haenlein [6], it is important to train people with digital skills, namely, basic knowledge of AI and programming, to respond to the companies that are looking for professionals for technical staff, with a need for knowledge in the areas of technology and innovation [19].

In terms of participation in innovation and development projects, both in the interviews $(70 \%)$ and the questionnaires $(43.2 \%)$, it was found that a large part of the interviewees and respondents have already participated in innovation and research projects with the purpose of technological and digital development of the organisation in which they work or of society.

\subsubsection{Contribution}

Interviewees and respondents were also asked about the influence of higher education on regional digital development and conveyed their perception of the contribution of higher education in preparing students for the labour market.

In the analysis of the interviews it was found that higher education provides a part of the necessary tools required by the labour market, but another part is acquired with professional experience, "It was the kick-off, it gave the tools and the will to analyze and do new research, to learn to think, to be mentally available and to know how to look for the right people to solve problems, but the training itself, in computer terms no". It was also discussed that young graduates do not have sufficient knowledge or skills to work in their area of training, "Most students have no idea what a company is. If we are training people to join companies, they must have at least knowledge of how a company is organized, at administrative, human resources, legal and legal levels". There is also a lack of monitoring of younger people by colleagues with more professional experience: "with the global economy, most companies no longer have money to accompany younger people, they just want people to be efficient (...), this can trigger "( . . ) psychological tension and professional discomfort (... )". This fact was also observed in the literature review, when [8] revealed that a large number of graduates lack the knowledge and attitude necessary for professional activity in their area of training. As for the questionnaires, in the question about the tools acquired in higher education being the necessary for the labour market, in general, the respondents revealed a neutral position. 
Regarding, the influence of higher education on regional digital development, it was found that, in general, HEIs contribute positively to regional development. This opinion was unanimous both in the analysis of the interviews and in the questionnaires. In the questionnaires, participants also indicated that higher education influences employment, quality of life at work $(89.2 \%)$, and the increase of knowledge and skills (56.8\%), at a regional level.

Again, the results of the interviews and the questionnaires are in line with the literature review. There is a positive relationship between higher education growth and regional economic growth [20], especially with regard to polytechnic higher education, which is sometimes located in the less developed regional areas. Polytechnic higher education, plays a very important role in regional development [53], because its training offer has been developed to meet the needs of the labour market in the regions [38].

After gathering all the conditions, such as the literature review, the analysis of the interviews and the analysis of the questionnaire results, the answers to the research questions are presented in next section.

\subsection{Presentation of the Answers to the Research Questions}

The main motivations for companies to adopt the digital transformation, answer to RQ1, are competitiveness, customer expectations, business growth and business model innovation, namely, customer contact, process optimization, information collection, control, and cost reduction.

In terms of the skills necessary for young people to enter the labour market, in response to RQ2, are technical and scientific knowledge at a technological level, such as programming and AI, flexibility and the ability to adapt to the business world, as well as, differentiated training. Although people have an engineering background, for example, they must also have knowledge of areas of management, tax law and business administration, among others. Like a person trained in law, they must have knowledge of the basics of programming and mathematics, which are the basis of technological evolution, and of management and business intelligence tools.

In response to question RQ3, to respond to the digital evolution of society, HEIs have adopted strategies to keep up with the labour market. The competitiveness in higher education has been growing and HEIs have been changing their teaching methods to more interactive methods that stimulate students' motivation.

With the new paradigms of teaching, namely distance learning, HEIs have invested in a series of software and tools to meet the needs of teachers and students. The tools most referred to throughout the interviews were Moodle, Zoom and Teams, and software in the management area, such as SAP. These tools are also used as a complement to face-to-face teaching. The HEIs also offer training to management bodies, teachers, and the remaining academic community so that they may be in line with the school's objectives, which is, from the technological perspective, to prepare and train students, future managers, and company employees for the challenges of an increasingly digital world. HEIs have also formulated courses and trainings for professionals who want to acquire new skills or reinforce knowledge.

However, it should be considered that the strategy of HEIs varies according to their school typology, because an engineering school has different objectives from a business school. For example, engineering schools train people with high digital skills who are able to innovate and program, whereas the function of business schools is to improve business models and add value to the digital.

Regarding question RQ4, in the analysis of the interviews and questionnaires, the results revealed that HEIs contribute to the digital development of the regions, especially in the regions where they operate. The participants indicated that higher education contributes to job creation, to the improvement of the quality of life at work and to the acquisition of knowledge and skills. It is also important to mention that there has been a greater involvement 
between higher education and the labour market, namely through research centres, business consultancy and the development of partnerships with local entities.

Finally, in response to the main question, "What is the influence of Public Polytechnic Institutes in the region of the Metropolitan area of Porto on regional digital development?", according to the size of our sample and the data collected, we can conclude that, in general, Polytechnic Institutes, positively influence the digital development of regions, through the training of technicians in scientific and economic areas of each region [53]. Which translates, as mentioned earlier in the response to RQ4, into job creation, improved quality of life and the acquisition of knowledge and skills, important to meet the labour market needs in the regions [38]. The influence of Educational Institutions is not only confined to the region where they are located, but also, to the neighbouring regions, however, this effect has a greater impact in the less developed regions of the country [20].

\section{Conclusions}

This research aimed at understanding the importance of digital transformation and Industry 4.0 in society and not only identifying its advantages and disadvantages. As well as understand the efforts made by HEIs to keep up with this evolution and the influence they represent for the regions and consequently for the economic and social development of the Country.

After reviewing the literature and analyzing the empirical data, it was concluded that: (a) the main motivations for companies to adopt the digital transformation are competitiveness, customer expectations, business growth and business model innovation; (b) the key challenges of digital transformation are cultural and behavioural resistance; lack of change-oriented mindset; lack of understanding of digital trends; low functional collaboration; (c) the main competences and participation are acquiring new skills to respond to the new demands and evolution of the labour market; participation in applied research projects and innovation; and (d) regarding the influence of higher education on regional development, they Influence employment and quality of life at work; increase knowledge and skills; provide differentiated training; technical and scientific knowledge; flexibility and adaptability. In conclusion, HEIs transmit part of the necessary tools required by the labour market, but another part is acquired through professional experience.

It is also concluded that the digital transformation and Industry 4.0, are an enormous contribution to the development of companies in several sectors and in the most diversified areas, namely, at the financial and accounting level. Besides being areas that, in comparison with the industrial sector, require a lower investment for the implementation of new innovation systems, they are areas that, when developed, bring countless benefits for companies. Especially, when it comes to data communication, to generate and report information to decision makers [54]. AI systems are information systems that solve problems to achieve the best outcome based on the available data. Paschen [55] argues that companies should integrate AI for knowledge management and for sharing quality information, without errors and with less costs. However, it is important to be aware that AI can help create information, but people have to know how to interpret it [55].

Throughout this study some difficulties were experienced in obtaining answers to the research questions. One of the main difficulties experienced was in eliciting responses to the questionnaires. Although the questionnaire was widely disseminated, we were not able to obtain the desired number of responses. One of the reasons, may have been, because the theme is about Industry 4.0, people do not have knowledge about the concept and did not adhere to the questionnaire.

As research proposals, it is proposed that the study be replicated in other regions of the country and also in other countries. It is also proposed to carry out a study of the implementation of Industry 4.0 in companies, by sector.

Once this research work is concluded, it is expected that it may contribute to future works and knowledge enrichment, at the level of digital transformation and development of higher education. 
Author Contributions: Conceptualization, A.F.T. and M.J.A.G.; methodology, M.J.A.G. and A.F.T.; validation M.J.A.G. and M.d.L.M.T.; formal analysis, M.J.A.G. and M.d.L.M.T.; investigation, A.F.T.; writing—original draft preparation, A.F.T.; writing—review and editing, A.F.T. and M.J.A.G.; visualization, M.d.L.M.T.; supervision, M.J.A.G. and M.d.L.M.T.; project administration, M.J.A.G.; funding acquisition, M.J.A.G. All authors have read and agreed to the published version of the manuscript.

Funding: This work is financed by portuguese national funds through FCT-Fundação para a Ciência e Tecnologia, under the project UIDB/05422/2020.

Conflicts of Interest: No conflict of Interest.

\section{References}

1. Staub, D. "Another accreditation? what's the point?" effective planning and implementation for specialised accreditation. Qual. High. Educ. 2019, 25, 171-190. [CrossRef]

2. Transformação Digital-O Guia Completo. WayTrends. 2018. Available online: https://www.waynext.com/waytrends/ transformacao-digital-guia-completo/ (accessed on 30 April 2020).

3. Mushore, R.; Kyobe, M. Optimizing the business value of digital transformation by aligning technology with strategy, work practices and stakeholder interests. In Proceedings of the 2019 IEEE 10th Annual Information Technology, Electronics and Mobile Communication Conference (IEMCON), Vancouver, BC, Canada, October 2019; pp. 403-408. [CrossRef]

4. Ghobakhloo, M. Industry 4.0, digitization, and opportunities for sustainability. J. Clean. Prod. 2020, 252, 119869. [CrossRef]

5. Sallati, C.; de Andrade Bertazzi, J.; Schützer, K. Professional skills in the Product Development Process: The contribution of learning environments to professional skills in the Industry 4.0 scenario. Procedia CIRP 2019, 84, 203-208. [CrossRef]

6. Kaplan, A.; Haenlein, M. Rulers of the world, unite! The challenges and opportunities of artificial intelligence. Bus. Horiz. 2020, 63, 37-50. [CrossRef]

7. López-Fernández, D.; Sánchez, P.S.; Fernández, J.; Tinao, I.; Lapuerta, V. Challenge-Based Learning in Aerospace Engineering Education: The ESA Concurrent Engineering Challenge at the Technical University of Madrid. Acta Astronaut. 2020, 171, 369-377. [CrossRef]

8. Martins, F.J.; de Abreu, P.H.C.; Simon, A.C. A EVOLUÇÃO DO ENSINO SUPERIOR E SUAS IMPLICAÇÕES: UMA VISÃO SOBRE O CONTEXTO PROFISSIONAL DIANTE DE CENÁRIOS COMPLEXOS E INOVATIVOS. (Portuguese). Available online: http:/ / nucleus.feituverava.com.br/index.php/nucleus/article/view/3042 (accessed on 19 May 2020).

9. WEF. Here's How Digital Transformation Will Create a More Sustainable World. World Economic Forum. 2020. Available online: https://www.weforum.org/agenda/2020/01/digital-transformation-sustainable-world/ (accessed on 19 May 2020).

10. Durão, N.; Ferreira, M.J.; Pereira, C.S.; Moreira, F. Current and future state of Portuguese organizations towards digital transformation. Procedia Comput. Sci. 2019, 164, 25-32. [CrossRef]

11. Mergel, I.; Edelmann, N.; Haug, N. Defining digital transformation: Results from expert interviews. Gov. Inf. Q. 2019, $36,101385$. [CrossRef]

12. Tekic, Z.; Koroteev, D. From disruptively digital to proudly analog: A holistic typology of digital transformation strategies. Bus. Horiz. 2019, 62, 683-693. [CrossRef]

13. Banelienè, R.; Melnikas, B. Economic Growth and Investment in R\&D: Contemporary Challenges for the European Union. Contemp. Econ. 2020, 1, 21.

14. Ferreira, C.A.A.; Natário, M.M.S.; Braga, A.M.M. Análise e avaliação ao funcionamento dos clusters em Portugal reconhecidos pelo QREN. Econ. Soc. Territ. 2018, 57. [CrossRef]

15. Martin, R.; Sunley, P. Conceptualizing Cluster Evolution: Beyond the Life Cycle Model? Reg. Stud. 2011, 45, 1299-1318. [CrossRef]

16. Porter, M.E. Clusters and the New Economics of Competition. Harv. Bus. Rev. 1998, 76, 77-90.

17. Branco, A.; Lopes, J.C. Cluster and business performance: Historical evidence from the Portuguese cork industry. Investig. Hist. EconÓMica 2018, 14, 43-53. [CrossRef]

18. Da Conceição Gonçalves, V.; Mendes, F.R.; Sardinha, I.D.; Rodrigues, R. Twenty years after the Porter Report for Portugal. Compet. Rev. 2015, 25, 540-554. [CrossRef]

19. Veiga, F.; Alexandre, F.; Cerejeira, J.; Arezes, P.F. O Crescimento da Economia Portuguesa. Estudo Para a Associação Missão Crescimento, Escola de Economia e de Gestão da Universidade do Minho, Portugal. 2019. Available online: https://www.eeg. uminho.pt/pt/investigar/nipe/Documents/Crescimento\%20Economia\%20Portuguesa.pdf (accessed on 19 May 2020).

20. Valero, A.; Van Reenen, J. The economic impact of universities: Evidence from across the globe. Econ. Educ. Rev. 2019, 68, 53-67. [CrossRef]

21. Leal Filho, W.; Skouloudis, A.; Brandli, L.L.; Salvia, A.L.; Avila, L.V.; Rayman-Bacchus, L. The role of higher education institutions in sustainability initiatives at the local level. J. Clean. Prod. 2019, 233, 1004-1015. [CrossRef]

22. Peer, V.; Penker, M. Higher Education Institutions and Regional Development: A Meta-analysis. Int. Reg. Sci. Rev. 2016, 39, 228-253. [CrossRef]

23. Sivarajah, U.; Irani, Z.; Gupta, S.; Mahroof, K. Role of big data and social media analytics for business to business sustainability: A participatory web context. Ind. Mark. Manag. 2020, 86, 163-179. [CrossRef] 
24. Guinan, P.J.; Parise, S.; Langowitz, N. Creating an innovative digital project team: Levers to enable digital transformation. Bus. Horiz. 2019, 62, 717-727. [CrossRef]

25. Kipper, L.M.; Furstenau, L.B.; Hoppe, D.; Frozza, R.; Iepsen, S. Scopus scientific mapping production in industry 4.0 (2011-2018): A bibliometric analysis. Int. J. Prod. Res. 2020, 58, 1605-1627. [CrossRef]

26. Porter, M.; Linde, C. Green and competitive: Ending the stalemate: M.E. Porter and C. van der Linde. Harv. Bus. Rev. 1995, 73, 120-134. [CrossRef]

27. Tiwari, K.; Khan, M.S. Sustainability accounting and reporting in the industry 4.0. J. Clean. Prod. 2020, 258, 120783. [CrossRef]

28. UNESCO. Investir na Ciência, Tecnologia e Investigação, Comissão Nacional da UNESCO. 2020. Available online: https: // unescoportugal.mne.gov.pt/pt/temas/ciencia-para-um-futuro-sustentavel/investir-na-ciencia-tecnologia-e-investigacao (accessed on 23 April 2020).

29. European Commission. Regional Innovation Scoreboard. Internal Market, Industry, Entrepreneurship and SMEs-European Commission. 2019. Available online: https:/ / ec.europa.eu/growth/industry/policy/innovation/regional_en (accessed on 18 May 2020).

30. Pinto, M.; Leite, C. Digital technologies in successful academic itineraries of higher education non-traditional students. Educ. $E$ Pesqui. 2020, 46, 1-17. [CrossRef]

31. Lašáková, A.; Bajzíková, L'; Dedze, I. Barriers and drivers of innovation in higher education: Case study-based evidence across ten European universities. Int. J. Educ. Dev. 2017, 55, 69-79. [CrossRef]

32. UoF. BACKGROUND. Universities of the Future. Available online: https:// universitiesofthefuture.eu/background/ (accessed on 17 May 2020).

33. Di Gregorio, A.; Maggioni, I.; Mauri, C.; Mazzucchelli, A. Employability skills for future marketing professionals. Eur. Manag. J. 2019, 37, 251-258. [CrossRef]

34. Tsai, Y.-S.; Rates, D.; Moreno-Marcos, P.M.; Muñoz-Merino, P.J.; Jivet, I.; Scheffel, M.; Drachsler, H.; Delgado Kloos, C.; Gašević, D. Learning analytics in European higher education-Trends and barriers. Comput. Educ. 2020, 155, 103933. [CrossRef]

35. Caliari, K.V.Z.; Zilber, M.A.; Perez, G. Tecnologias da informação e comunicação como inovação no ensino superior presencial: Uma análise das variáveis que influenciam na sua adoção. REGE-Rev. Gest. 2017, 24, 247-255. [CrossRef]

36. Pinho, C.; Franco, M.; Mendes, L. Exploring the conditions of success in e-libraries in the higher education context through the lens of the social learning theory. Inf. Manage. 2020, 57, 103208. [CrossRef]

37. Law No. 62/2007, of 10 September. Diário da República n. ${ }^{\circ}$ 174/2007-Série I. Regime Jurídico das Instituições de Ensino Superior. Available online: https:/ / dre.pt/application/file/640244 (accessed on 10 August 2020).

38. De Lourdes Machado-Taylor, M.; Soares, V.M.; Teichler, U. Challenges and Options: The Academic Profession in Europe; Springer International Publishing: Berlin, Germany, 2017. [CrossRef]

39. P.PORTO. Apresentação-P.PORTO | Ensino Superior Público. Available online: https://www.ipp.pt/apresentacao (accessed on 10 May 2020).

40. Cerdeira, L.; Cabrito, B.G.; Mucharreira, P.R. O Crescimento Do Ensino Superior No Portugal Democrático: Evolução Da Pós-Graduação E Da Produção Científica. EccoS-Rev. Científica 2019, 51, 1-24. [CrossRef]

41. Martínez-Campillo, A.; Fernández-Santos, Y. The impact of the economic crisis on the (in) efficiency of public Higher Education institutions in Southern Europe: The case of Spanish universities. Socioecon. Plann. Sci. 2019, 100771. [CrossRef]

42. Ambrósio, S.; e Sá, M.H.A.; Simões, A.R. Lifelong Learning in Higher Education: The Development of Non-traditional Adult Students' Plurilingual Repertoires. Procedia-Soc. Behav. Sci 2014, 116, 3798-3804. [CrossRef]

43. Wolszczak-Derlacz, J. An evaluation and explanation of (in) efficiency in higher education institutions in Europe and the U.S. with the application of two-stage semi-parametric DEA. Res. Policy 2017, 46, 1595-1605. [CrossRef]

44. Ryan, B.; Scapens, R.W.; Theobald, M. Research Method and Methodology in Finance and Accounting, 2nd ed.; Cengage Learning: Hampshire, UK, 2002.

45. Fortin, M.F. O Processo de Investigação: Da Concepção à Realização; Lusociência- Edições Técnicas e Científicas Lda: Loures, Portugal, 1999.

46. Fontana, A.; Frey, J. The Interview: From Structured Questions to Negotiated Text. Handbook of Qualitive Research; SAGE Publications: Thousand Oaks, CA, USA, 2000.

47. Silverman, D. Interpreting Qualitative Data: Methods for Analysing Talk, Text, and Interaction, 2nd ed.; SAGE Publications: London, UK, 2001.

48. Holstein, J.A.; Gubrium, J.F. The Active Interview; SAGE Publications: Thousand Oaks, CA, USA, 1995.

49. Teixeira, A.F. A Influência das Instituições de Ensino Superior para o desenvolvimento digital da região Norte. 2021. [CrossRef]

50. How the Digital Transformation Can Put Humans at the Centre of Robotics and Automation. In European Economic and Social Committee, 22 April 2020. Available online: https:/ / www.eesc.europa.eu/en/our-work/publications-other-work/publications/ how-digital-transformation-can-put-humans-centre-robotics-and-automation (accessed on 12 May 2020).

51. Project Activities-Projeto U-Value. Available online: http://wordpress.ubi.pt/uvalue/atividades-do-projeto/ (accessed on 12 May 2020).

52. Sousa, M.J.; Baptista, C.S. Como Fazer Investigação, Dissertações, Tese e Relatórios-Segundo Bolonha, 5a . Pactor-Edições de Ciências Sociais, Forenses e da Educação. 2014. Available online: https:/ / www.wook.pt/livro/como-fazer-investigacaodissertacoes-tese-e-relatorios-cristina-sales-baptista/11006357 (accessed on 10 April 2020). 
53. Urbano, C. A (id) entidade do ensino superior politécnico em Portugal: Da Lei de Bases do Sistema Educativo à Declaração de Bolonha / La (id) entidad de la enseñanza superior politécnica en Portugal: De la ley de bases del sistema educativo a la Declaración de Boloña / Essence and identity in polytechnic higher education in Portugal: From the basic law on the educational system to the Bologna Declaration / L'(id) entité de l'enseignement supérieur polytechnique au Portugal: De la loi de bases du système éducatif à la Déclaration de Bologne. Sociol. Probl. E PrÁTicas 2011, 66, 95-115.

54. Stanciu, A.; Petrescu, M.; Petrescu, A.G.; Bîlcan, F.R. Cyberaccounting for the Leaders of the Future. Improving Business Performance Through Innovation in the Digital Economy. 2020. Available online: www.igi-global.com/chapter/cyberaccounting-for-the-leadersof-the-future/236932 (accessed on 30 December 2020).

55. Paschen, J.; Wilson, M.; Ferreira, J.J. Collaborative intelligence: How human and artificial intelligence create value along the B2B sales funnel. Bus. Horiz. 2020, 63, 403-414. [CrossRef] 